\title{
INITIAL EXPLORATION OF A PROTECTION SYSTEM FOR HISTORICAL AND CULTURAL TOWNS AND VILLAGES IN HAINAN, CHINA
}

\author{
WANG ZHENYU \\ Department of Architecture and Urban Planning, Huazhong University of Science and Technology, China
}

\begin{abstract}
The long course of Chinese national history runs from a remote source. Since China has a vast territory, different regions formed a variety of regional cultures with different natural environments and era evolutions. Historical and cultural towns and villages not only exist as individual entities, but also as integrated urban and rural settlements and regional cultures. This paper presents the methodologies for the protection of historical towns and villages in the phase of systematic planning in Hainan Province. The research begin with looking at Hainan's regional culture, adopting the research method of anthropology and regional heritage to retrace the culture of Hainan's towns and villages, analysing the status quo, and on this basis, building a framework of Hainan historical towns and villages in promotion of its rational protection and development.

Keywords: historical and cultural towns and villages, land use, Meso-scale space unit, non-motorvehicle travel.
\end{abstract}

\section{INTRODUCTION}

Hainan is a tropical island in southern China with beautiful scenery; its special natural environment has created an exotic culture. Today, most people see Hainan as an international scenic spot; however, less attention is paid to Hainan's culture and traditions, which, to some extent, results in a lack of cultural construction. Historical and cultural villages and towns are important space carriers of Hainan culture; therefore, the construction of provincial-level historical and cultural towns and villages to protect the historical and cultural heritage of Hainan is essential.

Protection System Planning of historical and cultural towns and villages is based on cultural systems, spatial structure systems, the protection of directory systems, the value systems and other factors, and its purpose is to protect the system's construction. There are many historical and cultural heritages at the provincial level in Hainan Province, and research on the planning and protection of historical and cultural villages and towns has its own characteristics. Therefore, the study of regional historical and cultural towns and villages needs to find new breakthroughs. Therefore, with the starting point of regional culture, and on the basis of analyzing the origin of the local culture and the status quo of the villages and towns, this paper constructs a framework for a system of the protection of historical and cultural towns and villages systematically through combing, integration and comprehensive evaluation methods, and proposes its protection strategy.

\section{CULTURAL ORIGIN}

Hainan is an island on the south edge of China with a tropical climate and clearly possesses the characteristics of a tropical climate. Isolated from the mainland, Hainan's residents are mainly immigrants that live on the island. These two factors are the basic element of the 'tropical island culture' and 'multi-ethnic immigrant culture'. 


\subsection{Tropical island culture based on the natural environment}

Hainan Island is China's southernmost mainland island. Located at the north edge of tropical zone, it has the reputation of being a 'natural greenhouse'. With the help of a tropical monsoon climate, Hainan has a beautiful agricultural environment, and has made Hainan a winter resort and a blessed land in Chinese culture. Hainan is a typical island, with coastal plains on four sides and mountainous regions in the middle. In ancient times, mountainous regions in central Hainan were the place that ethnic groups would gather; meanwhile, the ethnic Han gather on its coastal plains and have produced a lot of poetry that describe the beauty of the seaside (Savi [1]) (see Fig. 1).

Ocean culture is the most important cultural background of Hainan Province. The sea is turbulent and unpredictable, reflected in the fearless spirit of Hainan people, as well as the openness and worship of trading (He Yi [2]). Sea worship, marine customs, marine-trading culture, and so on, have become an important base for historical towns in Hainan. At the same time, tropical culture and rainforest culture also affects the daily life of Hainan Han nationality (see Table 1).

\subsection{Multi-ethnic migration culture based on the historical environment}

Around ten to twenty thousand years ago, the ancestors of the Li ethnic group lived on the island, and there were a number of immigrants from Lingnan district that came to Hainan Island. From the Qing, Han Dynasty to the Ming and Qing Dynasties, the central government endured the jurisdiction of Hainan Island in the Qin Dynasty; the initial setting in Western Han Dynasty abandoned this jurisdiction and it later became controlled remotely in the Eastern Han Dynasty, the restart in Southern Dynasties Liang during Emperor Liangwu, immigrants in Southern Song and so on. In 1958, Haikou opened a port for trading, which brought to Hainan Island a combination of Chinese and Western colonial culture; it became the hometown to many overseas Southeast Asians, and thus, a multicultural society.

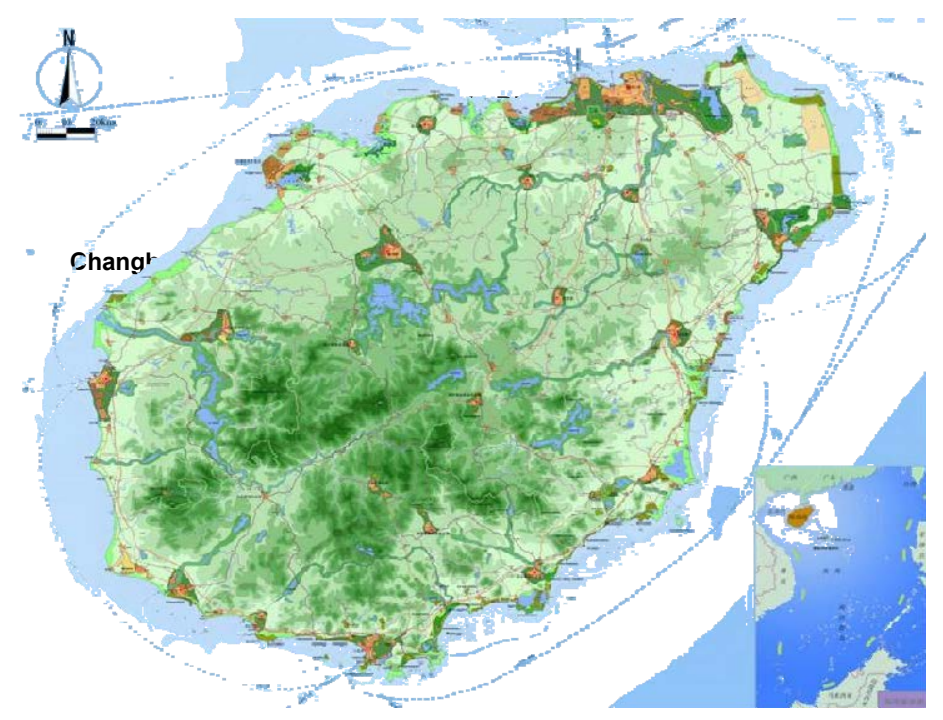

Figure 1: Hainan's landform and hydrograph. 
Table 1: Analysis of the structure of Hainan's tropical island culture. (Source: consolidation according to the author's own research material.)

\begin{tabular}{|c|c|c|c|}
\hline $\begin{array}{l}\text { Subject } \\
\text { culture }\end{array}$ & Derived culture & Cultural features & Cultural expressions and material space carriers \\
\hline \multirow{4}{*}{ Sea culture } & Beach culture & Poseidon worship & $\begin{array}{l}\text { Many coastal fishing ports, historical towns, sea } \\
\text { temples }\end{array}$ \\
\hline & $\begin{array}{l}\text { Intertidal-zone } \\
\text { culture }\end{array}$ & Farming in the sea & Silver Ocean, Pearl County is rich in shellfish pearls \\
\hline & Fisheries culture & Fisherman character & Live in the ship, accompanied by the sea \\
\hline & Trading culture & Trade in the sea & $\begin{array}{l}\text { Silk Road in Hainan, hometown of overseas Chinese, } \\
\text { coachman in South China Sea }\end{array}$ \\
\hline \multirow{3}{*}{$\begin{array}{l}\text { Forest } \\
\text { culture }\end{array}$} & Mountain culture & $\begin{array}{l}\text { Advocating } \\
\text { individuality }\end{array}$ & $\begin{array}{l}\text { Li and Miao ethnic group settlement, mountain culture } \\
\text { conservation }\end{array}$ \\
\hline & Rainforest culture & Original containment & $\begin{array}{l}\text { Prehistoric cultural sites, acres of coconut trees, } \\
\text { revolution culture }\end{array}$ \\
\hline & ure & 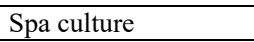 & Volcanic rock house, spa, life-preserving culture \\
\hline \multirow{3}{*}{$\begin{array}{c}\text { Tropical } \\
\text { architecture }\end{array}$} & Living culture & Free and light & $\begin{array}{l}\text { Architectural permeability and light, outdoor } \\
\text { activities, arcade }\end{array}$ \\
\hline & $\begin{array}{l}\text { Life-preserving } \\
\text { culture }\end{array}$ & Holiday theme & $\begin{array}{l}\text { Taoist holy health in ancient times, and now winter } \\
\text { vacation health }\end{array}$ \\
\hline & $\begin{array}{l}\text { Agriculture and } \\
\text { forestry culture }\end{array}$ & seasons harvest & $\begin{array}{l}\text { Farming all year-round, a wide variety of villages and } \\
\text { towns diversification }\end{array}$ \\
\hline
\end{tabular}

Table 2: Analysis of the structure of Hainan's multi-ethnic migration culture. (Source: consolidation according to the author's own research material.)

\begin{tabular}{|c|c|c|c|}
\hline $\begin{array}{l}\text { Subject } \\
\text { culture }\end{array}$ & Derived culture & Cultural features & Cultural expressions and material space carriers \\
\hline \multirow{2}{*}{$\begin{array}{l}\text { Tribal } \\
\text { culture of } \mathrm{Li} \\
\text { Miao ethnic } \\
\text { group }\end{array}$} & Li culture & $\begin{array}{l}\text { Gathering in } \\
\text { Mountainous } \\
\text { areas }\end{array}$ & $\begin{array}{l}\text { Acre system, spinning and weaving embroidery art, } \\
\text { tattoo, boat house }\end{array}$ \\
\hline & Miao culture & Subordinate status & Batik technology, bite-fixing, Miao Village \\
\hline \multirow{5}{*}{$\begin{array}{l}\text { The culture } \\
\text { of Han } \\
\text { immigrants }\end{array}$} & Frontier culture & $\begin{array}{l}\text { Defense and self- } \\
\text { government }\end{array}$ & $\begin{array}{l}\text { Lonely islands, defense of foreign enemies, away } \\
\text { from the political center }\end{array}$ \\
\hline & $\begin{array}{l}\text { Demotion } \\
\text { culture }\end{array}$ & Celebrities & $\begin{array}{l}\text { Immigration benefits, culture, academy, contenting } \\
\text { with poverty }\end{array}$ \\
\hline & Hoklo culture & Immigrant & $\begin{array}{l}\text { Analogous courtyard, side door folk houses, small } \\
\text { yards, low-key }\end{array}$ \\
\hline & Clan culture & Ancestor worship & $\begin{array}{l}\text { Beyond all ancestor worship, family-based, ancestral } \\
\text { hall/main room }\end{array}$ \\
\hline & $\begin{array}{l}\text { Multi-god } \\
\text { culture }\end{array}$ & Multi-god faith & $\begin{array}{l}\text { Buddha, Road, Poseidon, Guan Gong, Fubo, Xian } \\
\text { Lady Temple }\end{array}$ \\
\hline \multirow{3}{*}{$\begin{array}{l}\text { Overseas } \\
\text { culture }\end{array}$} & $\begin{array}{l}\text { Hui ethnic } \\
\text { culture }\end{array}$ & $\begin{array}{l}\text { Move in form } \\
\text { overseas }\end{array}$ & Tang tombs, Hui villages, masonry mosques \\
\hline & $\begin{array}{l}\text { Colonialist } \\
\text { culture }\end{array}$ & $\begin{array}{l}\text { A combination of } \\
\text { Chinese and } \\
\text { Western elements }\end{array}$ & $\begin{array}{l}\text { Haikou port, Christianity, Chinese and Western } \\
\text { combination architecture }\end{array}$ \\
\hline & $\begin{array}{l}\text { Overseas } \\
\text { Chinese } \\
\text { Culture }\end{array}$ & $\begin{array}{l}\text { Southeast Asia } \\
\text { characteristics }\end{array}$ & $\begin{array}{l}\text { Arcade characteristics of Commercial Street, } \\
\text { Southeast Asia style houses }\end{array}$ \\
\hline
\end{tabular}


The historical background of multi-ethnic migration has formed the multi-inclusion social culture in Hainan Island. Hainan culture is one part of the Chinese culture, Confucianism and Taoism both have great effect, it is neutral and moderate, and showed the unity of man and nature; these cultures are homologous with the mainland culture. However, as a small isolated island, Hainan does not have a centralized mode of 'unified' culture. Hainan culture is more about self-defense, ancestor worship, with Nanyang characteristics in recent decades, and the culture tends to have a multi-culture character (Yan Guanglin [3]) (see Table 2).

\subsection{The influence of regional culture on historic towns and villages}

Environment is the natural basis for the regional and social culture if Hainan. All cultures and characters are based on this background (Pickard [4]). Marine culture and Han immigrant culture in Hainan are dominant in Hainan regional culture. The development of marine culture created the cultural characteristics of immigrants in Hainan. These cultural characteristics all constitute the growth of the Hainan cultural village context.

Immigrants' culture from the mainland is an important component of the culture of Hainan Island. The main immigrants are from Fujian Province, which became the main culture of Hainan culture. Influenced by Fujian culture, doors of buildings in Hainan are open on the sides, and the clan halls are highly decorative, acting as the center of historical and cultural villages and towns (see Fig. 3). 'Celebrity guests' with 'immigration benefits' have more effect than estimated. Su Dongpo, the great poet in the North Song Dynasty, was demoted to Hainan, and pushed forward the development of Hainan culture and education; through his efforts, a large number of academies and ancestral halls were established (see Fig. 2). Modern Southeast Asian culture brought over by immigrants also brought about Chinese characteristics and culture.

Hainan historical and cultural villages and towns have more emphasis on the integration of the natural environment and marine culture, and Taoism also has a certain relationship. The Taoist emphasizes environmental integration; Hainan local buildings are usually located near water, mountains, fields, or near traffic lines. There are mountains, rivers, and green forests on Hainan Island, so when choosing settlement sites, people near the sea see 'hide wind and hold water' very important, due to the ideological form influenced by the tropical island culture and the mainland's farming civilization, which reflect Chinese philosophy and its 'Emphasis on Taoism and despising Confucianism'.

\section{TYPE ANALYSIS}

At present, there are numerous historical and cultural towns and villages in Hainan, in which more than 40 clusters are included in the provincial list. In the research, we found that there are far more clusters that should be taken into account. The author analyzed in more than 200 historical and cultural towns or villages, and conducted typological research, looking at aspects such as the ecological environment, social life, etc.

\subsection{Natural cluster types under environment of the tropical island}

\subsubsection{Waterfront type}

Hainan's civilization has benefited from its marine civilization to a great extent, of which there is a large proportion in the total number. The waterfront type includes the gulf coast type, the riverside near the estuary entrance type, the riverside near sea type, the plain seaside type, plain riverside type, riverside type and other subcategories. Ancient coastal 


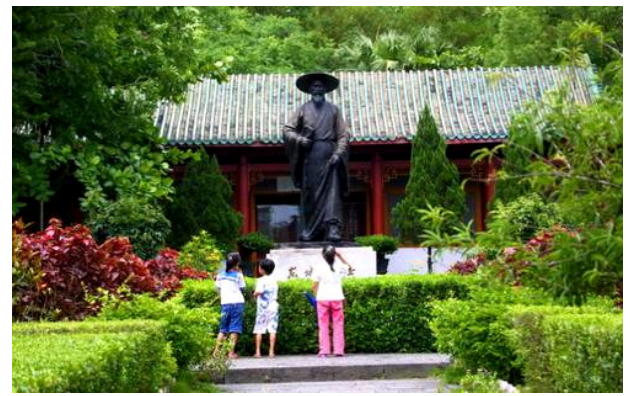

Figure 2: Demotion culture delegate Dongpo Academy.

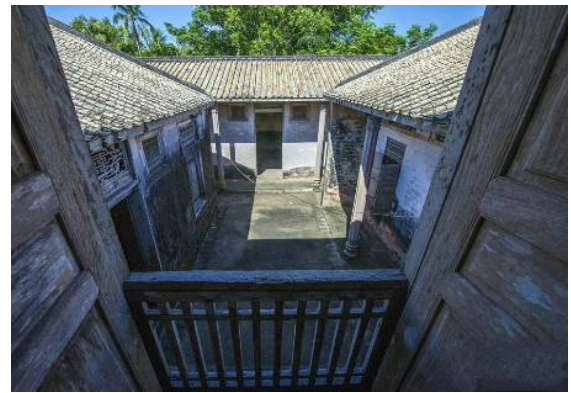

Figure 3: Holo culture quadrangle courtyard houses.

settlements are usually for the sake of fisheries or port business, so the site is usually selected in the Gulf or near the estuary where moorings are less affected by storms, and the layout of the clusters of space are arranged along the water distribution (see Fig. 4).

\subsubsection{Among-hills type}

There are more Li and Miao ethnic group towns and villages in the Wuzhishan area, which has a favorable environment and free layout. The Li ethnic group is very powerful, and, hence, dominates the best location for settlement. These locations are more located on the foot of the hills and face farmland fields or water, or between two hills. The Miao ethnic group are more located half way up the hill, inside the hylaea. There are also some mountainous towns in Han cultural hilly area (see Fig. 5).

\subsubsection{Plain type}

The plains of the mainland are easy for farmland cultivation, so the Han group are prone to choose the east and north side of Hainan Province. The plain type has strong characteristics; with a fan-shape, every courtyard develops with the main axis, forming its centripetal layout, which can be rarely seen in other areas in China (see Fig. 6).

\subsection{Functional cluster under the background of immigrant culture}

\subsubsection{Political type}

This is the cluster on the basis of ancient settlement. From the time of Emperor $\mathrm{Wu}$ to the Ming and Qing dynasty, once the government built several counties in Hainan, such as Zhonghe Town, the former site of Dan'er County in Xihan Dynasty, and Yacheng Town, the former site of Yazhou in Nan Dynasty. the space layout is built on the basis of ritual culture, and it has the characteristics of a city wall, the core of a Confucian Temple, etc. (see Fig. 7).

\subsubsection{Trading type}

Typical karma settlements are settlements that rely on commercial trade. Most cities and towns in China have commercial service functions, lead to numerous industry-based towns and villages in China. Most political cities and the port towns in Hainan serve a commercial function. Merchants gathered in business-type villages and towns, and the commercial streets are typical space elements for business-type settlements (see Fig. 8). 


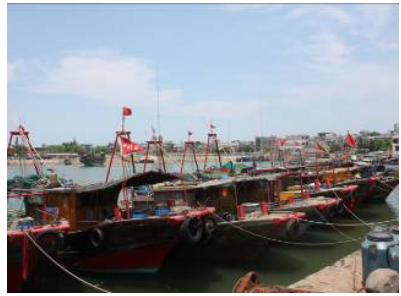

Figure 4: Xinying Town (waterfront type).

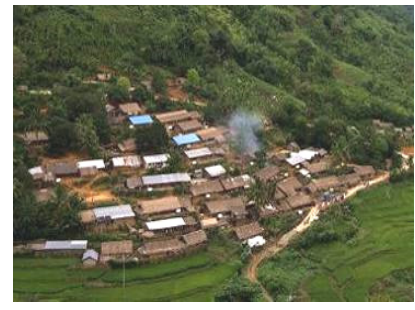

Figure 5: Chubao Village (among-hills type).

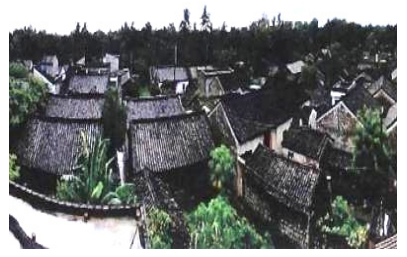

Figure 6: Dongtan Village (plain type).
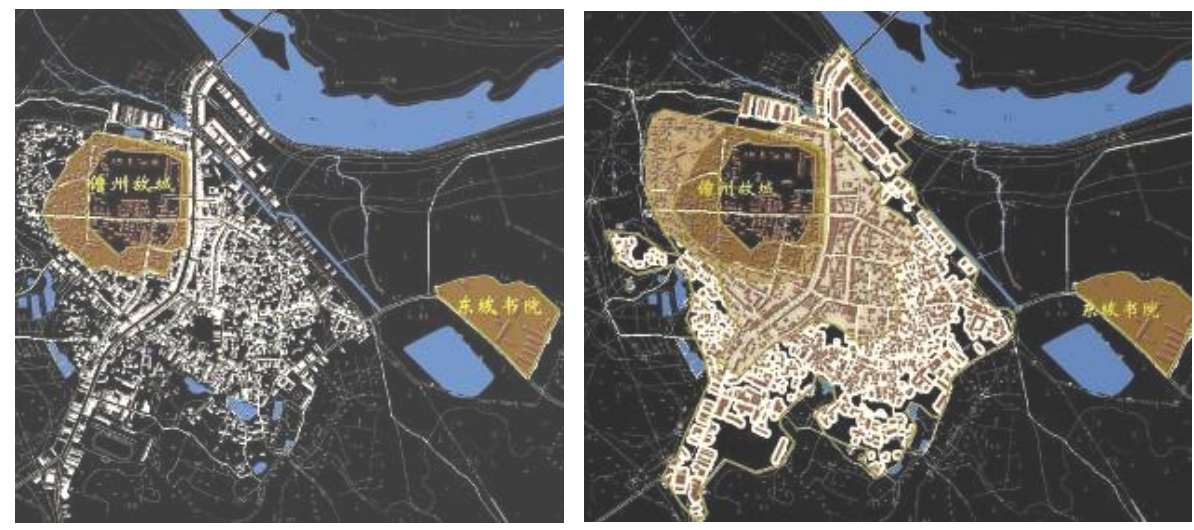

Figure 7: Transformation of political historical cultural Zhonghe Town.
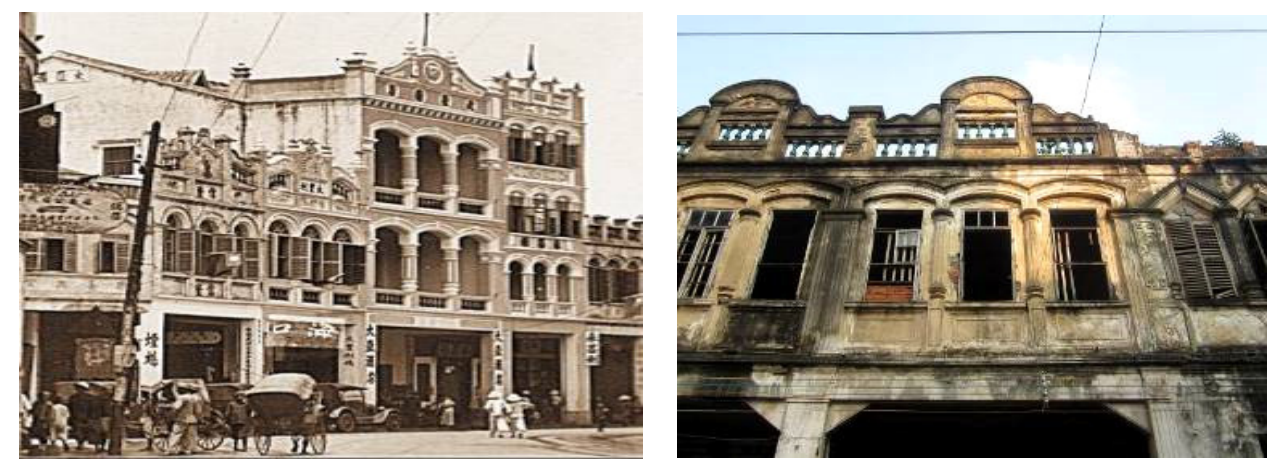

Figure 8: Wenchang verandah-street in the 1930s.

\subsubsection{Agricultural type}

Agricultural villages and towns account for the majority of the historical villages and towns. Amongst all Hainan provincial cultural towns, Xinpo Town, Shi Town serve the farming area within a certain distance. Most of the traditional villages in Hainan are agricultural 
villages and towns, there are geopolitical settlements and blood-type settlement, etc., most are ceremony-oriented, the ancestral hall is the center, and the buildings are analogous with traditional courtyards. In farming times, celebrities and wealthy businessmen would return to their hometown one retired and in promoting their homes, they would add more cultural value to the agricultural-style villages and towns (see Fig. 9).

\subsubsection{Fishery type}

Hainan is surrounded by the sea and has a great deal of fishing ports; hence, there are many fishing-type settlements there. Port-based villages and towns basically reflect the characteristics of the fishermen's ritual beliefs, and village settlements are based on different types of Poseidon temples as the core. Villages and towns are usually arranged along the coast or river bank; hence the concave shape of the harbor and the buildings that are usually arranged in an arc (see Fig. 10).

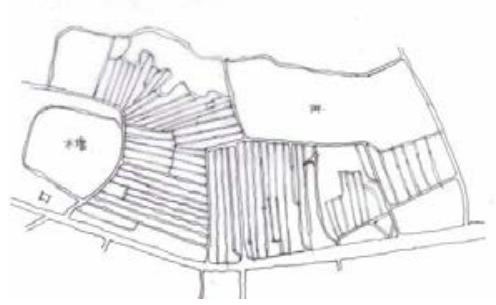

(a)

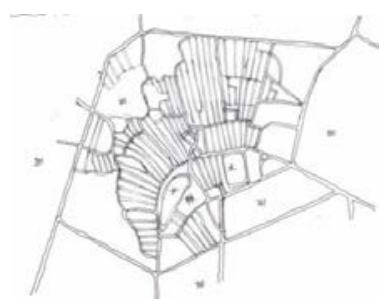

(b)

Figure 9: Comparison of the road network of (a) the Shilian Village (agricultural-area type) and (b) the Luoyi Village (agricultural-blood type).

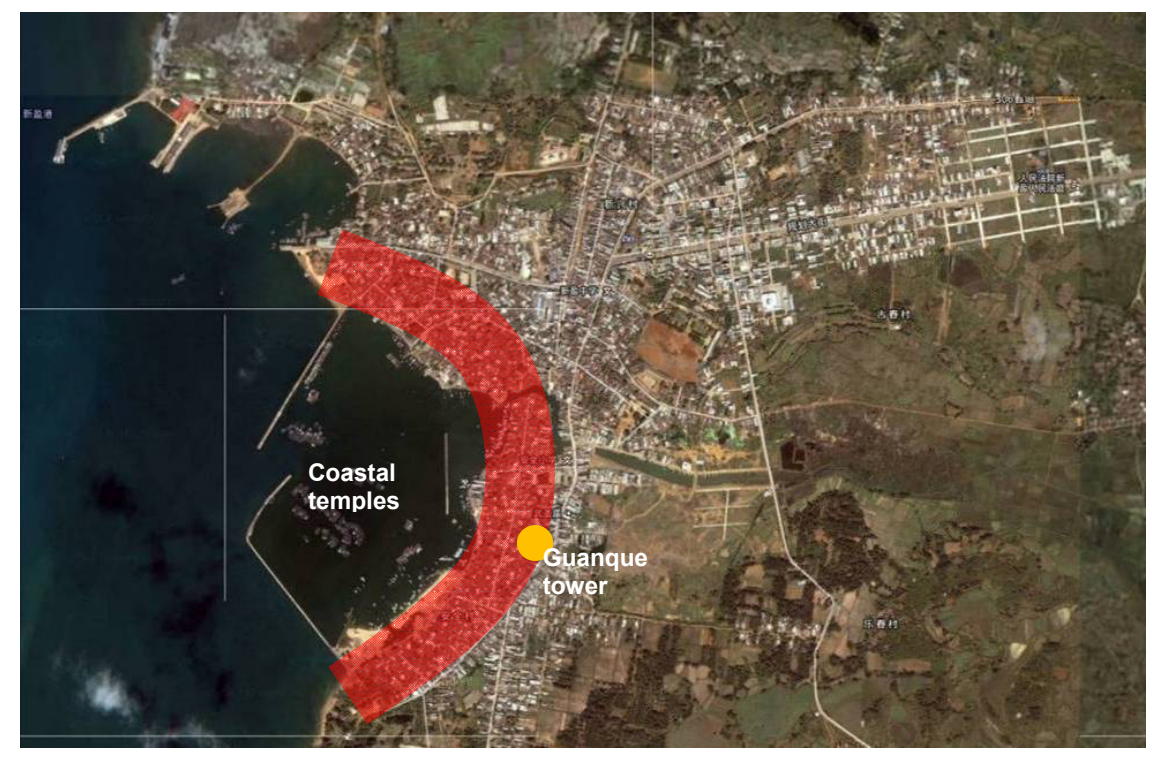

Figure 10: Satellite image of Xinying Town (fishery type). 


\subsubsection{Ethnical-basic type}

The main ethnic group villages and towns are Li and Miao villages and towns. They have their own rites and religious beliefs, and villages are centered on local rites or religious architecture. Ethnic compatriots usually have a talent for singing and dancing, so there are public spaces in villages and towns for these activities (see Fig. 11).

\subsection{Overall styles and features based on regional cultural}

Hainan's historical and cultural towns and villages are the complete products of Hainan's tropical island and sea environment, and of Hainan's multi-ethnic culture, which has the following characteristics:

The integration of multi-cultural settlements and a tropical island environment: with green trees, tiles, betel nuts, coconut, etc. (green everywhere!), this environment is refreshing, as if we are visiting Tao Yuanming's paradise, which is a common characteristic in Hainan's historical and cultural towns and villages.

Settlement patterns: architectural style is adapted to the hot climate in Lingnan region. Hainan coastal plains are hot and rainy, with perennial sea breeze or strong winds, which has a certain amount of salt, which is corrosive; hence, Ganlan wood buildings and wood structures are not suitable for multistorey building in Hainan.

Han immigrant culture occupies the dominant position. The majority of Hainan immigrants are from the Fujian Province, so the Fu Lao building decoration style and ancestral culture in Hainan can be seen easily. Fu Lao building is usually used to open the door on two sides in order to form a multi-type quadrangle residential characteristic; more into the courtyard lines change, and the plain settlements are formed with the characteristics of a fan.

Ocean culture has a far-reaching impact on settlement layout. Because of the coastal environment, buildings adopt strong anti-corrosion masonry structures. The architectural decoration also has a marine culture style with black low water plants, grass dragon patterns and so on. In modern times, Western culture was introduced into Hainan, forming the marine culture style of Hainan. Since the Republic of China era, the Chinese and Western arcade compound can be seen everywhere in Hainan, especially the coastal areas (Hao Shaobo [5]).

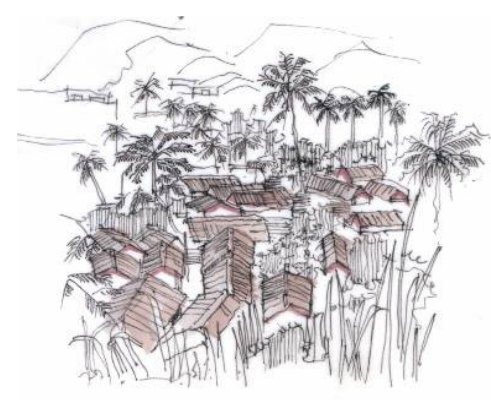

(a)

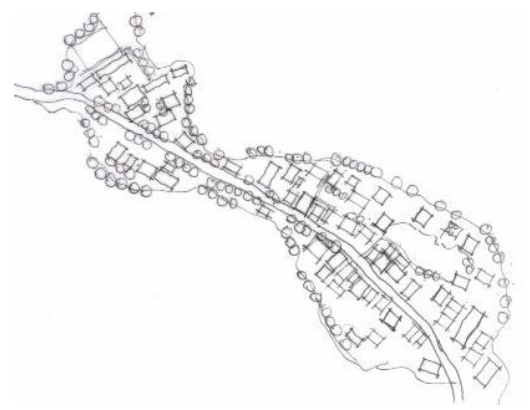

(b)

Figure 11: (a) Environmental and (b) architectural layout of Hongshui Village of Li ethnic group. 


\section{SYSTEM CONSTRUCTION}

Based on the analysis of Hainan regional culture and the typological analysis of historical and cultural villages and towns, this paper constructs a systematic framework for a historical and cultural towns and villages protection system within the region by examining the context and integrating resources.

\subsection{Context analysis - construction of cultural systems in towns and villages}

According to Hainan's historical and cultural characteristics, historical and cultural towns, cultural units, and intangible cultural heritage distribution, the Hainan Island can be divided into four historical and cultural districts: Qiongbei, Qiongdong, Qiongnan and Qiongxi. Both attached but also self-contained with prominent personality characteristics (see Fig. 12). We aim to interrogate the historical settlement submerged in the mountains and the sea, in combination with regional and cultural characteristics.

The cultural area of North Hainan Han emigration is Haikou/Danzhou, which is the more developed area of Hainan culture. During the period of the Han Dynasty, the government in West Han Dynasty set up Zhuya (now Qiongshan District, Haikou), Daner (now Zhonghe Town, Danzhou), and the Central Plains culture quickly spread to most parts of Hainan. In modern history Haikou created ports for trading, and Haikou became an important economic center; historical and cultural towns and villages in North Hainan are more representative of the farming culture of the arch, ancestral and other cultural heritage, also on behalf of the culture of the sea fishing temple and the Millennium ancient salt. East Hainan has Southeast Asian cultural aspects, with its center in Wenchang - the culture has been prosperous since ancient times, and modern marine culture communication makes the East Hainan region not only stand for the Han immigrants characteristics of the rich culture

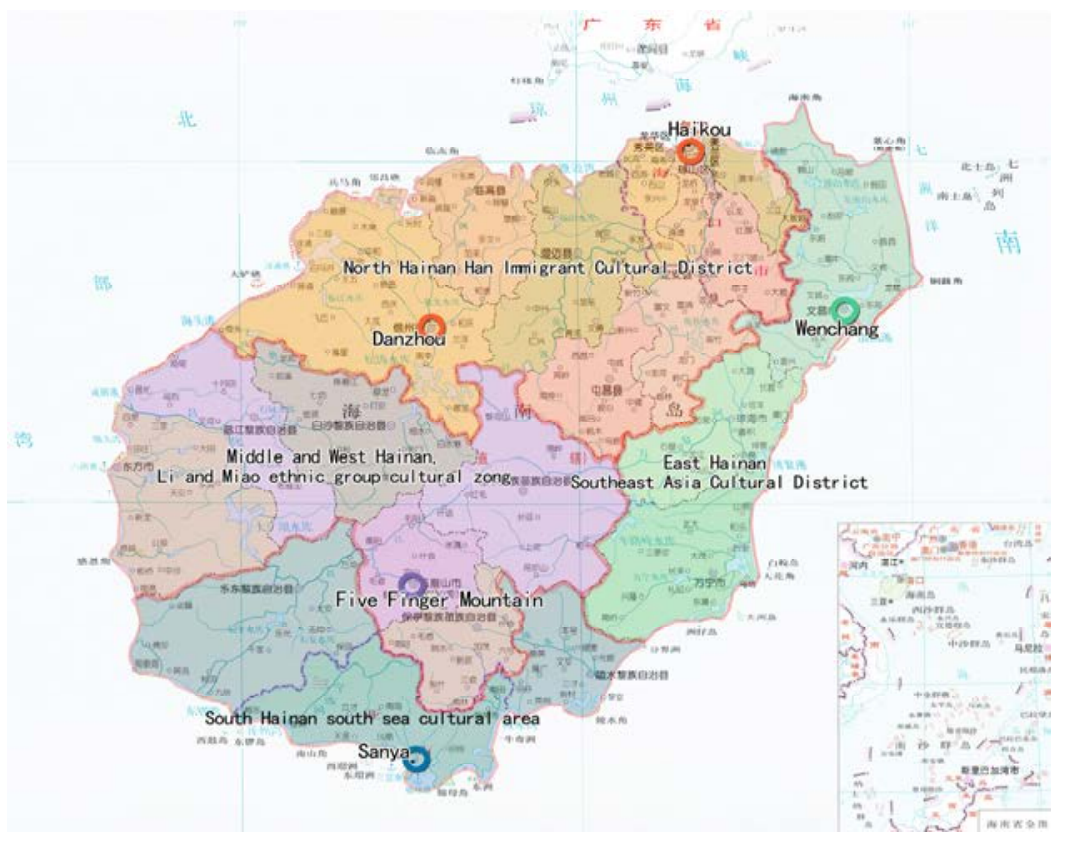

Figure 12: Historical map of Hainan's settlement culture. 
of the Hokou town, at the same time on behalf of the Southeast Asian cultural settlement. Sanya is the center of the South China Sea culture. Standing at the south end of China's land territory, it has strong cultural conclusion capability. There are Han Culture Village, Li Miao Culture Village, Dan Culture Fishing Village, and Hui Village, which represents the Islamic culture of the sea. The Wuzhishan area is the center of the Li Miao cultural zone in the middle and west part of Hainan, which mainly reflects the ethnic culture; Wuzhishan tropical rainforest style, the jungle landscape on the west coast of Hainan, therefore, forms the unique boat house and mountain settlements.

\subsection{Resource integration - construction of spatial structure system}

From the distribution of historical and cultural towns and villages in terms of the historical and cultural towns in Hainan, it has the characteristics of spatial clustering and regional differences. Historical villages are more concentrated in the coastal plains and riverside areas, such as Haikou as the center of forming historical and cultural towns and villages, and the formation of historical and cultural towns and villages' concentration zone along the southeast coast. Meanwhile, the number of historical and cultural villages and towns in the mountainous areas of central and western Hainan are comparably smaller. On the basis of the overall grasp of the historical development of Hainan, with the coastline culture as the main clue, secondary emphasis on national culture, hometown culture, mountain culture, connect through the traffic lines in a series, constituting a spatial pattern of 'double-core radiation + primary and secondary cultural clues + culture Patch' (see Fig. 13).

Its main center is Haikou and its surrounding areas, with Chinese culture, immigration culture, as the main body; the sub-center is the Wuzhishan area, with Li, Miao culture as the core. And further formed are the Danzhou Bay cultural plaques, the Pro West coastal

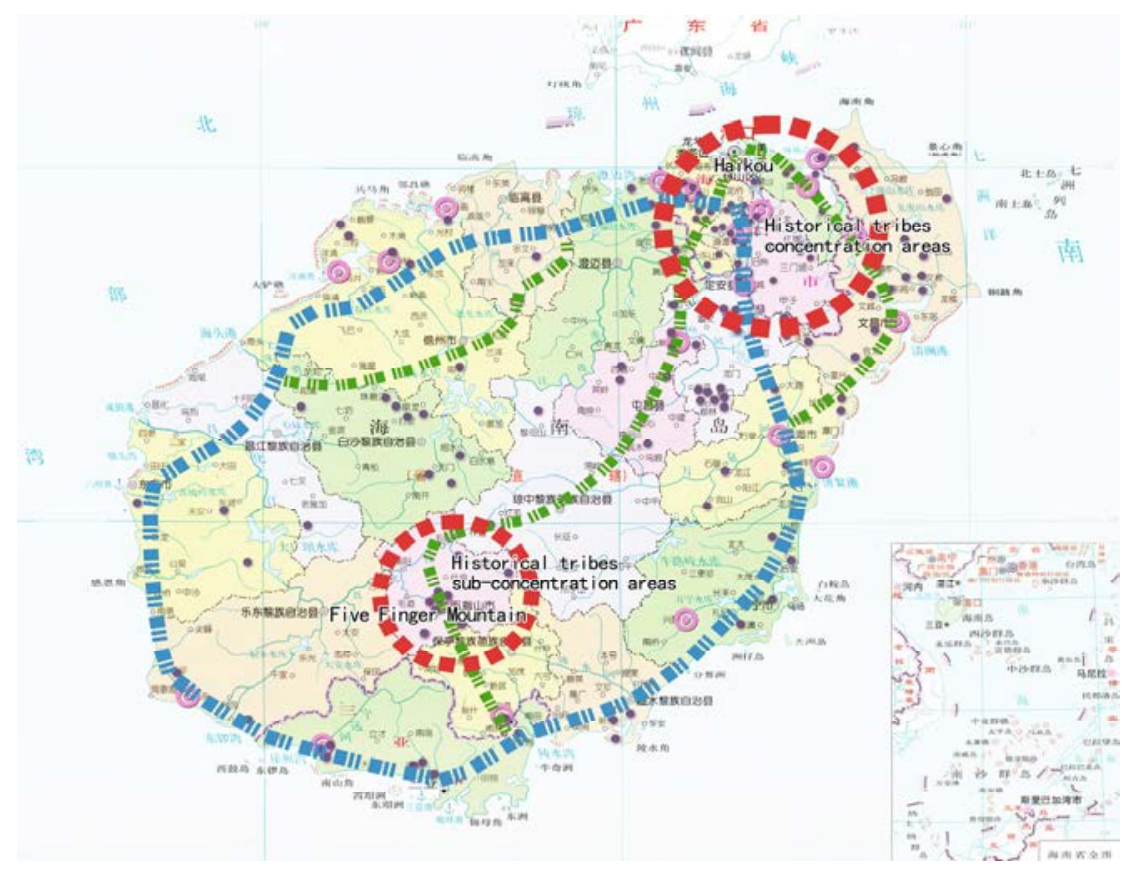

Figure 13: Cultural map of historical tribes in Hainan. 
patches, Wenchang East Coast patches, Dinganlongzhou River Basin patches, Wanquan River Basin plaque (Qionghai), East Coast patches (Wanning), Huanling Water Bay cultural patches, the South China Sea coast of Sanya patches, the West coast in east patches, Baisha Jakarta Ridge patches, and the 10 historical and cultural towns and villages cluster. With the formation of the systematic historical area, the main cultural lines, secondary cultural lines and cultural plaques as a framework system, we constitute a network of cultural space, to deepen understanding and enhance the value of the formation of the effect of the system.

\section{CONCLUSION}

Historical and cultural towns and villages belong to small historical settlements, and while today's big cities have homogeneity in the world, small historical settlements and their surrounding environments are worthier of protection (ICOMOS [6]). Thousands of years of cultural heritage, beautiful beaches, clear water, woods, combined with the unique Hainan courtyard houses, Li boat house, the combination of Chinese and Western arcades and modern residential dwellings are all important cultural symbols of Hainan. Historical and cultural villages and towns in Hainan Province are the carrier of the traditional regional culture of Hainan Island. Therefore, for the protection of historical and cultural towns and villages, a holistic investigation and study of the historical and cultural villages and towns and their regional environment must be conducted, to further analyze their unique characteristic value and protection connotation.

To build Hainan's historical and cultural towns and villages' framework at the provincial level, we should adopt the historical cultural plot units in patch protection, with the protection clues of historical and cultural paths to protect the cultural characteristics of historical and cultural towns. For example, the Southeast cultural district in east Hainan district highlights the arcade culture, and the protection of the South Pacific style compound, while the South Sea area near South Hainan cultural area highlights the marine frontier culture, and the need for tropical coastal environment protection, and the establishment of a number of historical and cultural fine lines, namely the East Coast coastal plain cultural routes, the West Coast coastal jungle cultural routes, the central tropical forest cultural lines, and cultural lines crisscrossing the island of Hainan.

All in all, Hainan has a strong geographical characteristic. The success of historical and cultural villages and towns' protection will directly influence the construction of regional culture and the development of Hainan. Only by paying attention to the construction and protection of Hainan's cultural heritage, can the regional culture of Hainan be perfected and developed.

\section{ACKNOWLEDGEMENT}

Project aided by the National Science Foundation (no. 51578256).

\section{REFERENCES}

[1] Savi, Hainan Local Chronicles. Years of the Republic of China. Lijiang Press, 2012.

[2] He Yi, The family lived in the tide of smoke, cultural reading on history town Shipu. City Planning Forum, 7, pp. 21-24, 2004.

[3] Yan Guanglin, History and Culture in Hainan. Social Sciences Academic Press, 2012.

[4] Pickard, R., Conservation in the Built Environment, Longman: Harlow, 1996.

[5] Hao Shaobo, Joan north of modern residence "Nanyang style" formation and changing. New Buildings, 5, pp. 38-42, 2011.

[6] ICOMOS, Declaration of Tlaxcala on the Revitalization of Small Settlements, 1982. 